\section{PP-265転移を有する尿路上皮癌症例に対す る外来維持化学療法}

\author{
愛媛大学医学部泌尿器科 \\ 尾澤 彰, 柳原 豊，池田 哲大，島本 憲司， \\ 青木 克徳, 丹司 望, 横山 雅好
}

進行性もしくは転移を有する尿路上皮癌に対し、当科では gemcitabine(GEM) と cisplatin(CDDP) 併用療法を採用し、良好な成績をあ げているが、從来の M-VAC療法と同梯にその奏功期間の短さが課題であ る。当科では、外来で維持投与できる化学療法を導入し、奏功期間の延長 を図っている。入院中にCDDPを含妉多剂併用療法を施行し、MR以 上の治㙩効果を得た 16 例 (年齢: $64-83$ 藏、中央値：71歳、全例PS1 以下）を対象に、1年を目標にGEMを中心にした多剂垪用療法を施行し た。GEM 単剂を投与した症例が 4 例、GEM と docetaxel(PTX) 両刘を併 用した症例が 9 例、GEM と白金製剂を侻用した症例が7例（う亏4例は GEM と PTX 併用療法後に再発した症例) であった。維持化学療法の治療 期間は 1-19 个月、観察期間は $1-39$ 个月、1. 病勢の増瑟により治療を中止 した症例が 5桝、2. 同しく病勢の增覀により GEM/CDDP 潦法など入院 による治療に移行した症例が 4 例、3.維持療法を完遂し、無治療期間内に 再発した症例が2例、4.その他の7例は無增悪にて継繶している。5.有害

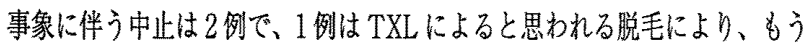
1例蛙瘤によるイレウス症状が強く、中止を希望した。その他の有害事 象は全身供总感や味覚異常、骨髄抑制なと軽度であった。維持化学療法は GEM/CDDP 併用療法の奏功期間を廷長させる可能性があると思われる。

\section{PP-266 尿路上皮がんに対するパクリタキセ ル及び壏酸ゲムシタビン併用化学療 法の臨床的模討}

山梨厚生病院泌尿器科 ${ }^{1)}$, 富士吉田市立病院 ${ }^{2}$ ，市立甲 府病院 ${ }^{3)}$, 山梨大学医学部泌尿器科 ${ }^{4)}$

滝花 義男 ${ }^{1}$, 石川 覚之 ${ }^{1)}$, 寺本 咲子 ${ }^{1)}$,

中込 宙史 ${ }^{1)}$, 小室 三津夫 ${ }^{2)}$, 川口 真琴 ${ }^{3)}$,

野澤 宗裕 ${ }^{3)}$ ，渡辺 健二 ${ }^{3)}$ ，亘沼 賢司 ${ }^{4)}$,

座光寺 秀典 ${ }^{4)}$, 荒木 勇雄 ${ }^{4)}$, 武田 正之 ${ }^{4)}$

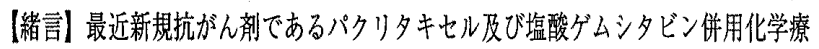
法が永路上皮がんで有效性が報告されている。今回山梨県 4 施設で施行されたパク

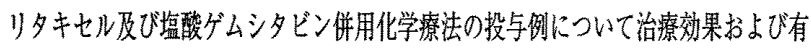

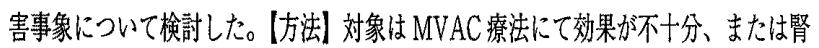

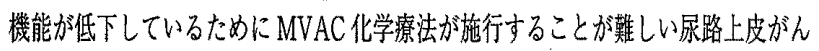

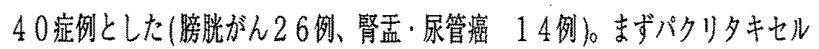

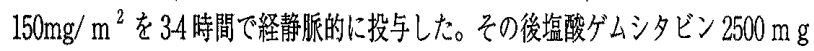
$/ \mathrm{m}^{2}$ を30分で投与した。二剂を二週間ごとに投与した。结顆治潦判定につい

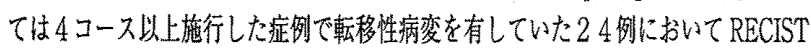

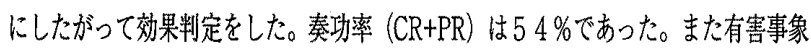
はNCI-CTC にしたがった。白血球涉少淀は grade 3 以上が $10 \%$ 、血小板橴少は

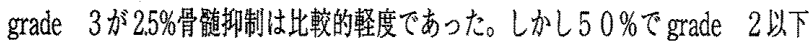
の知覚栍神経障害力゙出現した。さらに一例問質性肺炎によって死亡した。洘察】腎 機能低下例やMVAC 無效例に㧊いてはパクリタキセル及び塩酸ブムシタビン併用

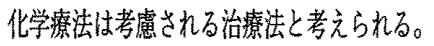

395 (444)

\section{PP-267}

尿路上皮癌に対する gemcitabine/ paclitaxel の 2nd line 化学療法とし て検討

\begin{abstract}
北里大学医学部泌尿器科学 ${ }^{1)}$, 日本銅管病院 ${ }^{2)}$, 北里研 究所病院 ${ }^{3)}$

坪井 俊樹 ${ }^{1)}$, 松本 和将 ${ }^{1)}$, 須山 - 穂 ${ }^{2)}$, 西 盛宏 ${ }^{1)}$, 平山 貴博 ${ }^{1)}$, 木村 将貴 ${ }^{13}$, 別所 英治 ${ }^{1)}$, 山田 泰史 ${ }^{1)}$, 佐藤 威文 ${ }^{11}$, 入江 啓 ${ }^{3)}$, 岩村 正嗣 ${ }^{12}$, 馬場 志郎 ${ }^{1)}$
\end{abstract}

目的：MVAC 酎性進行・再発尿路上皮癌に対する gemcitabine / paclitaxel (GT) 療法の 2nd line 化学㙩法としての有用性について 検討した。対象と方法：MVAC 療法を前治療として施行されてい る症例で、原発巣が組織学的に尿路上皮癌と診断され、画像検查 にて測定可能である局所浸潤病変または遠隔転移 (目的病変)を 認める上部尿路癌 5 例、膀胱癌 5 例について検討した。GT療法 の投与方法として paclitaxel $200 \mathrm{mg} / \mathrm{m} 2$ を dayl、gemcitabine $1000 \mathrm{mg} / \mathrm{m} 2$ を day $1 、 8 、 15$ に静脈内投与し、21 日を 1 コースと した。抗腫瘍効果は 2 コースごとに目的病変を画像にて測定し判 定した。結果：平均投与回数は 4 回 (2-7回) であり、CR 2 例、 PRを 5 例に認めた。全生存期間は 10.3 个月であり、MVAC 投与 時からは 19.1 ケ月であった。非再発期間は 4.1 ケ五であり、抗腫 瘍効果を認めた 7 例では 7.4 ケ月であった。副作用として骨髄抑 制や paclitaxelによる四肢の痺れを主に認めた。結論：GT療法は MVAC 療法後の症例に対して重篤な副作用も少なく、抗腫瘍効果 も認められ有用な2nd line 治療法と考号られた。

\section{PP-268}

尿路上皮癌術後補助化学療法後の再 発・転移に対する化学療法の効果

\begin{abstract}
福井大学医学部泌尿器科
伊藤 秀明, 土山 克樹, 山内 寛喜, 楠川 直也， 金田 大生, 前川 正信, 棚瀨 和弥, 青木 芳隆, 大山 伸幸, 三輪 吉司, 秋野 裕信, 横山 修
\end{abstract}

【目的】尿路上皮癌に対する手術後、high risk 症例飞対しては補助化学療 法を施行しているが、その後に再発した症列に纳治潦が困難である。今回 われわれは、術後補助化学㙩法後の再発に対寸る化学療法の効果を検詂し た。【対象と方法】1994年1月より2007年3月までに尿路上皮癌に対して

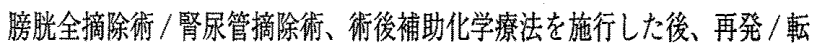
移を認めた 17 例（䐱脱癌 10 例、上部尿路上皮癌 3 例、併存 4 例)に対して 化学潦法を施行した。術後袺助寮法としてM-VAC が施行された 4 例々対

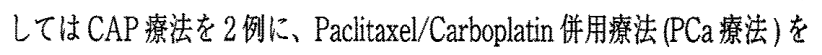
2例に施行した。術後補助療法としてPCa 療法力施行された 13 例に対し ては M-VACを7例、PCa療法を6例に施行した M-VAC が無効であ。 た6例中 3 例に対し、Paclitaxel/Carboplatin/Gemcitabine 併用澺法を2侧、

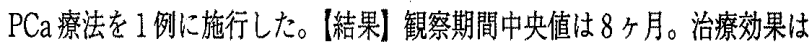
$\mathrm{CR} 1$ 例、PR5 例、 NC8 例、 $\mathrm{PD}$ 例で有效率は $35.3 \%$ 、奏彸期間は 4.52 个月 (中 央值5.5 月月)であった。生存期間は2.52 个月(中央值8 个月)であった。結 語】補助化学療法後の再発に対する M-VAC と PCa 療法の有効率に差的無 加た。少数例の経験ではあるが、他剂無效例にも Gemcitabine 考含んだ メニューは效果が認められ、今後期待される。 